\title{
EFFECT OF COMPANY VALUE, LEVERAGE, AND COMPANY SIZE ON PROFIT PERSISTENCE IN JAKARTA ISLAMIC INDEX (JII) LISTED COMPANIES
}

\author{
Budi Prasetyo $^{1)}$, Satiti Utami ${ }^{2)}$, Alwazir Abdusshomad ${ }^{3)}$, Mukti Wijaya ${ }^{4)}$, Nawang Kalbuana ${ }^{5)}$ \\ Politeknik Penerbangan Indonesia Curug ${ }^{1,2,3,5}$, Universitas Pramita Indonesia ${ }^{4}$ \\ E-mail : budi.prasetyo@ppicurug.ac.id ${ }^{1}$, satiti.utami@ppicurug.ac.id ${ }^{2}$, alwazir@ppicurug.ac.id ${ }^{3}$, \\ wijayamukti98@gmail.com ${ }^{4}$,nawang.kalbuana@ppicurug.ac.id ${ }^{5}$
}

\begin{abstract}
The purpose of this study was to determine the effect of Company Value, Leverage, and Company Size on Earnings Persistence in Companies Listed in the Jakarta Islamic Index (JII). Data obtained from the page www.idnfinancial.com. The data in this study are secondary data. The approach used in this research is a quantitative approach. Sampling technique using purposive sampling technique and data analysis using multiple linear regression analysis. Samples that fit the criteria were obtained by 23 companies during the 2015-2019 observation period. Then the data were analyzed using the SPSS data regression analysis model.26.0 The results showed that firm value had no significant effect on earnings persistence, leverage and firm size had a significant effect on earnings persistence on companies listed on the Jakarta Islamic Index (JII) for the 2015-2019 period.
\end{abstract}

Keywords: $\quad$ The Value of the Company; Leverage; Company Size; Earnings Persistence

\section{Introduction}

Financial statements are records of the company's financial information during an accounting period that can be used to describe the company's performance. The quality of a financial statement is generally required by investors and creditors who use financial statements for investment decision making (Putri \& Supadmi, 2016). One element of the financial statements used as the basis for decision making is profit information. Profit information is very important for related parties in the company, in estimating the company's future profit (Sutisna, 2017). So big is the role of profit information, the quality of profit becomes very important for decision makers. profit quality is the ability of profit in reflecting the correctness of the company's profit and helps predict future profit, taking into account stability and persistence (Utari \& Mertha, 2016).

Agustianto Research (2013) stated that profit is one of the important factors in estimating performance and as basic information for investors in conducting profit estimating. Through profit, investors and creditors can assess management performance, predict risks in investing and be able to predict the profit to be obtained in the future. Earnings information plays an important role in measuring net changes in shareholders' wealth and is an indication of the company's ability to generate profit. Signal theory explains that companies have an urge to convey information owned by the public in order to minimize information asymmetry. Profit information is a positive signal in the form of good news where the company always wants to report the information to the public in the hope that the market will react as soon as the profit announcement is delivered.

The profit generated by the company will affect the market response and share price movements. Investors are certainly happy if the company announces a high profit because 
investors will get dividends on each share ownership (Adriani, 2012). With a high level of profit and quality means the company gives a signal in the form of good news to the public so that investors' interest in investing is higher. Given the importance of profit information for investors.

The market reaction depends on the quality of the profit the company generates. Because profit can influence economic decisions made by users of financial statements, the profit is said to have information content. However, profit has limitations that are influenced by calculation assumptions and also the possibility of manipulation by the company's management so that it needs information other than profit to predict the return of the company's shares, namely the profit response coefficient or also called earning response coefficient (Tahir, 2016).

According to Djamaluddin et al (2008): "Quality profit is profit that can reflect the continuation of sustainable earnings in the future, which is determined by accrual and cash components and can reflect the company's true financial performance". The quality of a company's profit is often associated with profit persistence, because profit persistence is one component of predictive value of profit in determining profit quality (Suwandika and Astika, 2013). According to Penman (2003): "profit persistence is a profit that has the ability as an indicator of future earnings generated by the company repeatedly (repetitive) in the long term (sustainable)".

A component of the quality of profit is the persistence of profit. The quality of profit is determined based on qualitative characteristics in conceptual design, the time-based nature of profit, implementation decisions, and the relationship between profit, cash, and accrual processes (Jumiati \& Ratnadi, 2014). Profit persistence is classified in the time-based nature of profit, where profit information should be able to make a difference in decision making by helping users to make predictions from the past, present, and for the future (Zdulhiyanov, 2015). Profit persistence is a profit that tends not to fluctuate and reflects future sustainable earnings for long periods (Hui, Nelson, \& Yeung,2016). Companies that have unstable profits and fluctuating profits declined steeply to short-term losses indicating that they cannot reflect persistent profits (Putri \& Supatmini, 2016).

\section{Literarure Review}

\section{Agency Theory}

Jensen \& Meckling (1976) revealed that agency relationships are more than one person (employer or principal) who employs others (agents) some services that bequeath power in collecting and implementing a decision

\section{Company Value}

A company's value is a company's performance, which is reflected in the share price formed by the demand and supply of capital markets that reflect the public's assessment of the company's performance (Harmono, 2009).

According to Sujoko and Soebiantoro (2007) in Sri Hermuningsih (2009), the company's value is an investor's view of the company's success rate that is closely related to its share price. The high share price makes the company's value also high and increases market confidence in its current performance and the company's prospects. The share price used generally refers to the closing price and the price when the stock is traded on the market. Fakhruddin and Hadianto, 2001).

Company values can be calculated using the Price to Book Value (PBV) formula. According to Prayitno in Afzal (2012), Price to Book Value (PBV) shows how much the market 
International Journal of Economics, Business, and Accounting Research (IJEBAR)

Peer Reviewed - International Journal

Vol-5, Issue-1, 2021 (IJEBAR)

E-ISSN: 2614-1280 P-ISSN 2622-4771

https://jurnal.stie-aas.ac.id/index.php/IJEBAR

appreciates its shares' book value. The higher this ratio, means the market believes in the company's prospects. Pbv also shows how far a company can create relative value to the amount of capital invested. PBV can also mean a ratio that indicates whether the share price traded is overvalued (above) or undervalued (below) the book value of the shares (Fakhruddin and Hadianto, 2001).

\section{Leverage}

Leverage is a measure of how much a company is financed from debt. There will be an interest expense to be paid by the company from the use of a company's debt. The higher the ratio value to the company's leverage, the higher the interest costs arising from the debt, the higher interest costs affect the reduced tax burden of a company (Surya, 2016).

According to Cashmere (2009: 158), Leverage is the ratio used to see how much the company can pay all its obligations (both short-term and long-term obligations) to the state.

According to Atmaja (2008: 271), Leverage (debt ratio) demonstrates the company's ability to meet long-term obligations. The leverage Ratio shows the relationship between the company's debt to its own capital and assets. With this ratio, we can see how far the company is financed by debt or outside parties, with its ability described by its own capital or assets.

\section{Company Size}

The company's size is the scale of the company, as seen from the total value of the company's assets at the end of the year. Total sales are also used to measure the size of the company. Since the costs that follow sales tend to be greater, companies with high sales rates tend to choose accounting policies that reduce profits (Sidharta, 2000).

Research for the size of the company can use total assets as a benchmark because the company's total assets are of great value then this can be simplified by reforming into the natural logarithm (Ghozali, 2006)

\section{Profit Persistence}

Schipper and Vincent (2003), Francis et al. (2004) explained that: "persistence is a measure of profit quality based on the view that a more sustainable profit is a higher quality profit." Penman and Zhang (2002) define: "profit persistence as expected future earnings implied by the innovation of the year's profit." The size of this revision indicates the level of persistence of profit. In Wijayanti's research (2006): "Persistent profit is the profit that can reflect the continuation of future sustainable earnings determined by accrual components and cash flow."

The size of this revision indicates the level of persistence of profit. Profit is considered to be more persistent if the coefficient of variation is getting smaller. It can be concluded that the persistence of profit is the ability of profit now that is expected to be able to explain the profit in the future. Persistence can be seen based on the overall financial statements or measured based on the financial statements' components.

\section{Research Method}

This study used secondary data in the form of annual financial reports (financial reports) and companies registered in the Jakarta Islamic Index (JII) period 2015 - 2019. The financial report data was obtained from idn.financial.com. For share price data obtained from yahoofinance.com

The population in this research is a company registered in the Jakarta Islamic Index (JII) of 30 companies. The sample data used is as many as 23 companies, because 7 companies with 
International Journal of Economics, Business, and Accounting Research (IJEBAR)

Peer Reviewed - International Journal

Vol-5, Issue-1, 2021 (IJEBAR)

E-ISSN: 2614-1280 P-ISSN 2622-4771

https://jurnal.stie-aas.ac.id/index.php/IJEBAR

incomplete financial statements and in the form of dollar exchange rates are not with the rupiah value, so it is excluded from variables at the time of data processing that researchers do.

Dependent variables are variables that are affected or as a result, due to the free variable (Sugiyono, 2013). The bound variable in this study is tax Profit Persistence

Schipper and Vincent (2003), Francis et al. (2004) explained that: "persistence is a measure of profit quality based on the view that a more sustainable profit is a higher quality profit". Penman and Zhang (2002) define: "profit persistence as expected future earnings implied by the innovation of the year's profit." The size of this revision indicates the level of persistence of profit. In Wijayanti's research (2006): "Persistent profit is profit that can reflect the continuation of future sustainable earnings determined by accrual components and cash flow."

The size of this revision indicates the level of persistence of profit. Profit is considered to be more persistent, if the coefficient of variation is getting smaller. It can be concluded that the persistence of profit is the ability of profit now that is expected to be able to explain the profit in the future. Persistence can be seen based on the overall financial statements or measured based on the components of the financial statements. In this study, the authors used the same ratio as Persada (2010) which is a change in profit before tax in the current year consisting of pre-tax profit this year minus the previous year's profit before tax divided by total assets.

$$
P T B I=\frac{\text { Profit before tax } \mathrm{t}-\text { Profit before tax } \mathrm{t}-1}{\text { Total Assets }}
$$

An independent variable is a variable that affects or causes changes or the onset of bound variables. The free variables in this study are Company Value as $\mathrm{X} 1$, Leverage as $\mathrm{X} 2$, and Company Size as X3.

The value of a company is a performance of a company which is reflected in the share price formed by the demand and supply of capital markets that reflects the public's assessment of the company's performance (Harmono, 2009). Company values can be calculated using the Price to Book Value (PBV) formula. Systematically PBV can be calculated by the formula:

$$
\mathrm{PBV}=\frac{\text { Share price traded }}{\text { Book value of the share }}
$$

Leverage can be calculated using the DER (Debt to Equity Ratio) formula.

DER can be calculated by the formula:

$$
D E R=\frac{\text { Total Liabilities }}{\text { Total Equity }}
$$

The size of the company is the scale of the company as seen from the total value of the company's assets at the end of the year. Total sales are also used to measure the size of the company. Since the costs that follow sales tend to be greater, companies with high sales rates tend to choose accounting policies that reduce profits (Sidharta, 2000).

Research for the size of the company can use total assets as a benchmark, because the company's total assets are of great value then this can be simplified by reforming into the natural logarithm (Ghozali, 2006); so that the size of the company can also be calculated by: 
Schipper and Vincent (2003), Francis et al. (2004) explained that: "persistence is a measure of profit quality based on the view that a more sustainable profit is a higher quality profit". Penman and Zhang (2002) define: "profit persistence as expected future earnings implied by the innovation of the year's profit." The size of this revision indicates the level of persistence of profit. In Wijayanti's research (2006): "Persistent profit is profit that can reflect the continuation of future sustainable earnings determined by accrual components and cash flow."

The size of this revision indicates the level of persistence of profit. Profit is considered to be more persistent, if the coefficient of variation is getting smaller. It can be concluded that the persistence of profit is the ability of profit now that is expected to be able to explain the profit in the future. Persistence can be seen based on the overall financial statements or measured based on the components of the financial statements. In this study, the authors used the same ratio as Persada (2010) which is a change in profit before tax in the current year consisting of pre-tax profit this year minus the previous year's profit before tax divided by total assets.

$$
\text { Persistence }=\frac{\text { Profit before tax } \mathrm{t}-\text { Profit before tax } \mathrm{t}-1}{\text { Total Asset }}
$$

The formulation of the model in the study is titled Company Value, Leverage, and Company Size on Profit Persistence ". Dependent Variable Relationship (Y) is associated with an independent variable (X) used in the equation: Effect Of Company Value, Leverage, And Company Size On Profit Persistence In Jakarta Islamic Index (JII) Listed Companies $\mathrm{Y}=\mathrm{a}+\mathrm{b} 1 \mathrm{X} 1+\mathrm{b} 2 \mathrm{X} 2+\mathrm{b} 3 \mathrm{X} 3+\mathrm{b} 4 \mathrm{X} 4+\mathrm{e}$

Figure 1. Hypothetical Framework

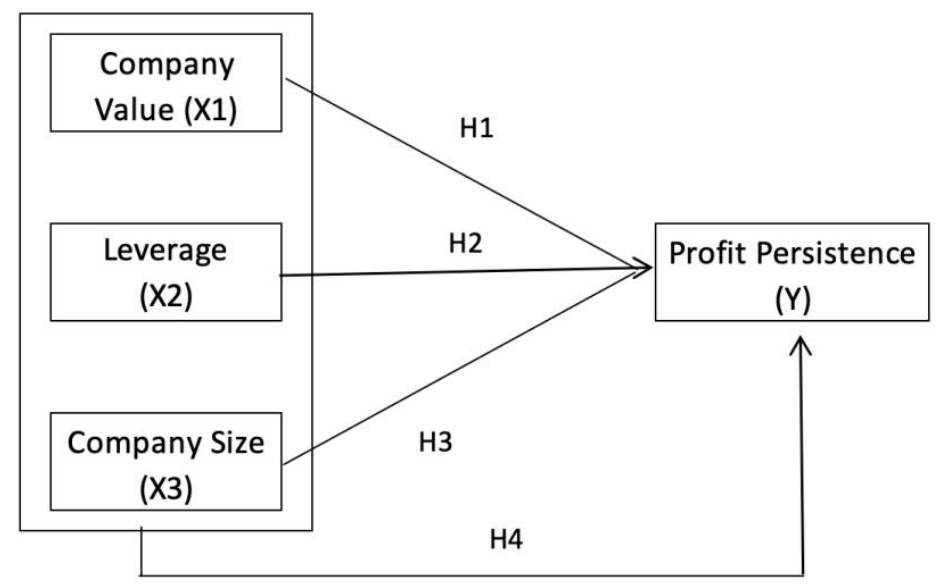

\section{Results and Discussion}

\subsection{Results}

The data analysis technique used in this study is Multiple Regression Analysis (MRA) or multiple linear regression analysis using the SPSS program. The results of the double linear regression analysis can be seen in Table 1 
International Journal of Economics, Business, and Accounting Research (IJEBAR)

Peer Reviewed - International Journal

Vol-5, Issue-1, 2021 (IJEBAR)

E-ISSN: 2614-1280 P-ISSN 2622-4771

https://jurnal.stie-aas.ac.id/index.php/IJEBAR

Table 1

Results of the double linear regression

\begin{tabular}{|c|c|c|c|c|c|c|c|c|}
\hline \multicolumn{9}{|c|}{ Coefficients $^{\mathrm{a}}$} \\
\hline \multirow[b]{2}{*}{ Model } & & \multicolumn{2}{|c|}{ Unstandardized Coefficients } & \multirow{2}{*}{$\begin{array}{c}\text { Standardized } \\
\text { Coefficients } \\
\text { Beta }\end{array}$} & \multirow[b]{2}{*}{$t$} & \multirow[b]{2}{*}{ Sig. } & \multicolumn{2}{|c|}{ Collinearity Statistics } \\
\hline & & B & Std. Error & & & & Tolerance & VIF \\
\hline \multirow[t]{4}{*}{1} & (Constant) & $-1,464$ &, 376 & & $-3,888$ &, 000 & & \\
\hline & $\mathrm{X} 1=$ Nilai Perusahaan & $2,499 \mathrm{E}-5$ &, 000 &, 133 & 1,449 &, 150 &, 870 & 1,149 \\
\hline & $X_{2}=$ Leverage & 208 &, 069 &, 263 & 3,026 &, 003 &, 963 & 1,038 \\
\hline & $\mathrm{X} 3=$ Ukuran Perusahaan &, 043 &, 012 &, 326 & 3,540 &, 001 & 860 & 1,163 \\
\hline
\end{tabular}

Secondary research data is said to be free from multilinearity problems if the Collinearity Statistics column shows tolerance results above 0.1 and Inflation Factor (VIF) Variation values of no more than $10(<10)$. From the results of the study that researchers conducted the data obtained tolerance results produced entirely above 0.1 and vif results are not more than $10(<10)$. This means that research data is free from multi-collocity problems.

Based on the table above can be created regression equations as follows: $\mathrm{Y}=-1,464+0,133 \mathrm{X} 1+0,263 \mathrm{X} 2+0,326 \mathrm{X} 3+\mathrm{e}$.

The $\mathrm{R}$ test aims to measure how far the model's capabilities explain variations in independent variables. The higher the coefficient value of the determination then the higher the ability of independent variables to explain the varibel dependent.

Table 2.

$\mathbf{U j i} \mathbf{R}^{2}$

\begin{tabular}{rr|r|r|r}
\hline Model & R & \multicolumn{1}{c}{ R Square } & \multicolumn{1}{c}{ Adjusted R Square } & \multicolumn{1}{c}{ Std. Error of the Estimate } \\
\hline 1 &, $439^{\mathrm{a}}$ &, 193 &, 171 &, 1225255 \\
\hline
\end{tabular}

Source : data produced, SPSS

Based on table 2 shows that the $\mathrm{r} 2$ value of 0.193 means that $19.3 \%$ variation in Profit Persistence rate change is influenced by of Company Value, Leverage, and Company Size. The remaining $69.1 \%$ was influenced by other factors not included in the research model.

\subsection{Discussion}

\section{Company Value (X1) to Lab Persistence}

The company's value in this study was proxyed on Equity (equity attributable to the owner of the parent entity), number of shares (issued and fully paid-up capital), share price (closing price of year-end shares), book value (equity divided by number of shares) and Price to Book Value (PBV) where the share price is divided by book value. Partial Test Results (Test $t$ ) conducted stated that the company's value has no significant effect on profit persistence by having a sig of 0.150 or $15 \%$. In simultaneous test results (Test F) states that the company's value has a significant effect on profit persistence with sig results of 0.000 or $0.0 \%$. And in the Partial Test Results (Regression Equation) the value of the company has a direct / positive effect on the persistence of profit, with beta the resulting influence is positive beta 
International Journal of Economics, Business, and Accounting Research (IJEBAR)

Peer Reviewed - International Journal

Vol-5, Issue-1, 2021 (IJEBAR)

E-ISSN: 2614-1280 P-ISSN 2622-4771

https://jurnal.stie-aas.ac.id/index.php/IJEBAR

\section{Leverage (X2) to Profit Persistence}

Leverage in this research is proxyed on total liabilities divided by total equity. The higher the ratio value to the leverage of a company, the higher the cost of interest arising from the debt. Partial Test Results (Test $t$ ) conducted stated that Leverage has a significant effect on profit persistence by having a sig of 0.003 or $0.3 \%$. In simultaneous test results (Test F) states that the company's value has a significant effect on profit persistence with sig results of 0.000 or $0.0 \%$. Similarly, the size of the company has a direct / positive effect on the persistence of profit, in the Partial Test Results (Regression Equation) with beta the resulting influence is positive beta. The results of this study are consistent with research conducted by Fanani (2010), Pagalung and Sudibdyo (2006), Cohen (2003), and Gu et al. (2002). Fanani's research shows that financial leverage has a positive effect on profit persistence, so the amount of financial leverage will cause the company to increase profit persistence with the aim of maintaining good performance in the eyes of investors and auditors.

\section{Company Size (X3) to Profit Persistence}

The size of the company in this study is proxyed on the logarithm of total assets. The greater the total assets of a company, it shows that the company is good, stable and more able to generate profit compared to companies with small total assets. Partial Test Results (Test $t$ ) in the company stated that the size of the company has a significant effect on the persistence of profit by having a sig of 0.001 or $0.1 \%$. In simultaneous test results (Test F) states that the company's value has a significant effect on profit persistence with sig results of 0.000 or $0.0 \%$. Similarly, the size of the company has a direct / positive effect on the persistence of profit, in the Partial Test Results (Regression Equation) with beta the resulting influence is positive beta. The results of this study supported pagalung and Sudibdyo research (2009), thatindicates that the size of the company has a positive effect on the persistence of profit. These results are also consistent with research by $\mathrm{Gu}$ et al. (2002), Cohen (2003), and Francis et al. (2006) which also found that the size of the company has a positive effect on profit persistence.

\section{Conclusion}

Based on the results of the spss test that has been done, it can be concluded that the company's value, leverage and size of the company have a significant positive influence simultaneously (f test) on the persistence of profit. While partial ( $\mathrm{t}$ test) leverage and company size have a significant positive influence on profit persistence, but the company's value has an insignificant positive influence on profit persistence in companies listed in the Jakarta Islamic Index (JII) for the period 2015 to 2019.

\section{Reference}

Anggraini, V. (2015). Pengaruh Islamic Social Reporting (ISR), Profitabilitas, dan Leverage Terhadap EarningResponse Coefficient (Studi Empiris Pada Perusahaan yang Terdaftar di Jakarta Islamic Index Tahun 2010-2013). Skripsi Jurusan Akuntansi Universitas Islam Negeri Syarif Hidayatullah, Jakarta.

Ardianti, R. (2018). Pengaruh Alokasi Pajak Antar Periode, Persistensi Laba, Profitabilitas, dan Likuiditas Terhadap Kualitas Laba (Studi Empiris Pada Perusahaan Manufaktur yang Terdaftar di BEI tahun 2012-2016). Jurnal Akuntansi Universitas Sarjanawiyata Tamansiswa, 6(1), 85 $\square 102$. 
International Journal of Economics, Business, and Accounting Research (IJEBAR)

Peer Reviewed - International Journal

Vol-5, Issue-1, 2021 (IJEBAR)

E-ISSN: 2614-1280 P-ISSN 2622-4771

https://jurnal.stie-aas.ac.id/index.php/IJEBAR

Arif, R. N. (2016). Faktor- Faktor yang Mempengaruhi Earning Response Coefficient (ERC) Pada Perusahaan yang Terdaftar di Bursa Efek Indonesia (Periode 2011-2015). Skripsi Jurusan Akuntansi Universitas Islam Negeri Syarif Hidayatullah, Jakarta.

Persada,A.E.,Martani D. 2010 .Analisis Faktor Yang Mempengaruhi Book-Tax Differences dan Pengaruhnya Terhadap Persistensi Laba.Jurnal Akuntansi \& Keuangan Indonesia,7(2).205-221.

Agus D. Hardjito, Martono. 2002. Manajemen Keuangan, Edisi Pertama, Ekonisia, Yogyakarta.

Ahmad, Rodoni dan Herni, Ali. 2010. Manajemen Keuangan. Penerbit Mitra Wacana Media, Jakarta.

Andreani dan Vera. 2014. Analisis Faktor-Faktor yang Mempengaruhi Persistensi Laba Pada Perusahaan Manufaktur di Bursa Efek Indonesia. Jurnal Wira Ekonomi Mikroskil Volume 4, Nomor 02, Oktober 2014

Erwin, Norita dan Vaya. 2017. Pengaruh Book Tax Differences Dan Aliran Kas Operasi Terhadap Persistensi Laba. Jurnal e-Proceeding of Management : Vol.4, No.1 April 2017

Mahendra dan Suardikha. (2020). Pengaruh Tingkat Hutang, FeeAudit, dan Konsentrasi Pasar Pada Persistensi Laba. e-Jurnal Akuntansi, Vol. 30 No. 1Denpasar, Januari 2020 Hal. 179-193.

Atmaja, Lukas Setia. 2008. Teori dan Praktek Manajemen Keuangan. Yogyakarta: Penerbit ANDI

Brigham dan Houston. 2010. Dasar-dasar Manajemen Keuangan. Jakarta: Salemba Empat.

Desiyanti, E., Kalbuana, N., Fauziah, S., \& Sutadipraja, M. W. (2020). Eka Desiyanti. MALA'BI: Jurnal Manajemen Ekonomi STIE Yapman Majene, 3(1), 1-5.

Fakhruddin, M dan M. Sopian Hadianto, 2001, Perangkat dan Model Analisis Investasi di Pasar Modal. Buku Satu. Jakarta: PT. Elekmedia Komputindo Kelompok Gramedia

Ghozali, Imam. 2006. Aplikasi Analisis Multivariate dengan Program SPSS (Edisi Ke 4). Semarang:Badan Penerbit Universitas Diponegoro.

Gumilang, Galang Surya. 2016. Metode Penelitian Kualitatif dalam Bidang Bimbingan dan Konseling. Jurnal Fokus Konseling, Vol. 2, No. 2, Hal:156.

Harmono, Dr. S.E, M.si, Manajemen Keuangan berbasis Balance Scored, Bumi Aksara, Jakarta, 2009.

Hermuningsih, Sri dan Dewi Kusuma Wardani. 2009. Faktor-Faktor yang Mempengaruhi Nilai Perusahaan yang Terdaftar di Bursa Efek Malaysia dan Bursa Efek Jakarta. Jurnal Siasat Bisnis Vol. 13 No. 2, Agustus 2009 Hal: 173-183. Universitas Sarjanawiyata Tamansiswa.

Home. James C. Van dan John M. Machowiecz. 2009. Prinsip-prinsip Manajemen Keuangan. Alih Bahasa: Dewi Fitriasari dan Deny Kwary. Jakarta: Salemba Empat.

Kalbuana, N., Yohana, Y., Permatasari, D., \& Fadila, Z. N. (2018). Pengaruh Tata Kelola Perusahaan Terhadap Kualitas Audit (Studi Empiris pada Perusahaan Food and Beverage yang terdaftar di Bursa Efek Indonesia). Seminar Nasional dan The 5th Call For Syariah Paper (SANCALL) 2018.

Kalbuana, N., Kurnianto, B., Saputro, R., Hendra, O., Utami, S., \& Widagdo, R. A. (2020). The Effect of Audit Quality, Managerial ownership, Institutional ownership, and Intellectual Capital toward Earning Management on Transportation Corporations in Indonesia. Solid State Technology, 63(5), 9176-9184.

Kalbuana, N., Widagdo, R. A., \& Yanti, D. R. (2020). Pengaruh Capital Intensity, Ukuran Perusahaan, Dan Leverage Terhadap Tax Avoidance Pada Perusahaan Yang Terdaftar Di Jakarta Islamic Index. Jurnal Riset Akuntansi Politala, 3(2), 46-59.

International Journal of Economics, Business, and Accounting Research (IJEBAR) Page 135 
International Journal of Economics, Business, and Accounting Research (IJEBAR)

Peer Reviewed - International Journal

Vol-5, Issue-1, 2021 (IJEBAR)

E-ISSN: 2614-1280 P-ISSN 2622-4771

https://jurnal.stie-aas.ac.id/index.php/IJEBAR

Kalbuana, N., Solihin, S., Yohana, Y., \& Yanti, D. R. (2020). The Influence Of Capital Intensity, Firm Size, And Leverage On Tax Avoidance On Companies Registered In Jakarta Islamic Index (Jii) Period 2015-2019. International Journal of Economics, Business and Accounting Research (IJEBAR), 4(03).

Kasmir. 2009. Analisis Laporan Keuangan. Rajawali Pers, Jakarta.

Kurnianto, B., Kalbuana, N., \& Rusiati, U. R. (2019). Pengaruh Good Corporate Governance, Profitabilitas, Leverage, dan Ukuran Perusahaan Terhadap Integritas Laporan Keuangan (Studi Empiris pada Perusahaan yang terdaftar di LQ45 Tahun 2014-2018).

Lamtiar, S., Arnas, Y., Rusdiyanto, A. A., Kalbuana, N., Prasetyo, B., Kurnianto, B., ... \& Utami, S. (2021). Liquidity Effect, Profitability Leverage to Company Value: A Case Study Indonesia. European Journal of Molecular \& Clinical Medicine, 7(11), 2800-2822.

Ningtyas, Pravitasari Eka dan Dini Widyawati. 2015. Pengaruh efektivitas penerapan standar akuntansi pemerintahan terhadap kualitas laporan keuangan pemerintah daerah. Jurnal Vol. 4 No. 1.

Purwanti, T., Kalbuana, N., \& Rahmawati, F. (2019). Pengaruh Good Corporate Governance, Audit Fee dan Kualitas Audit Terhadap Integritas Laporan Keuangan (Studi Empiris pada Perusahaan BUMN yang Terdaftar di BEI Tahun 2014-2018).

Sartono, A. 2010. Manajemen Keuangan Teori dan Aplikasi. Yogyakarta: BPFE Yogyakarta.

Sujoko dan Ugy Soebiantoro. 2007. Pengaruh Struktur Kepemilikan Saham, Leverage, Faktor Interen dan Faktor Eksteren terhadap Nilai Perusahan. Jurnal Manajemen dan Kewirausahaan. Vol 9, No. 1.

Sutadipraja, M. W., Kalbuana, N., Rahmawati, D., \& Desiyanti, E. (2020). Marista Winanti Sutadipraja. MALA'BI: Jurnal Manajemen Ekonomi STIE Yapman Majene, 3(1), 6-12.

Tarihoran, Anita. Pengaruh Penghindaran Pajak dan Leverage Terhadap Nilai Perusahaan dengan Transparansi Perusahaan Sebagai Variabel Moderasi. JWEM (Jurnal Wira Ekonomi Mikroskil) 6.2 (2017): 149-164.

Utama, Sidharta. 2000. Teori dan Riset Akuntansi Positif: Suatu Tinjauan Literatur. Jurnal Ekonomi dan Bisnis Indonesia. No. 1. Hal. 83-96

Yohana, Y., Kalbuana, N., Fadila, Z. N., \& Permatasari, D. (2018). Pengaruh Leverage dan Kualitas Audit Terhadap Volatilitas Saham (Studi Empiris pada Perusahaan Dagang yang terdaftar di Bursa Efek Indonesia). Seminar Nasional dan The 5th Call For Syariah Paper (SANCALL) 2018. 